\title{
A state-by-state look at biomedical issues
}

As John McCain and Barack Obama go head-to-head on the main playing field, it's easy to overlook the smaller battles happening on the sidelines. But congressional races, ballot proposals and gubernatorial face-offs are stirring debate across the country. Here Nature Medicine highlights a few contests that have the potential to affect to biomedical research. - By Coco Ballantyne

\section{WASHINGTON}

\section{Doctor-assisted suicide}

'Initiative 1000 ' is a citizen-driven proposal for a state statute that would permit doctors to assist in the suicides of terminally ill adults. Advocacy groups on both sides of the issue are orchestrating elaborate campaigns to persuade voters

\section{Gubernatorial race}

Four years ago, the incumbent governor, Democrat Chris Gregoire, managed to beat out Republican candidate Dino Rossi by a mere 129 votes. The same two candidates face off again this year, and the race is again looking close. During her term as governor, Gregoire worked with the state legislature to set up the Life Sciences Discovery Fund, which will distribute up to $\$ 350$ million in research grants over ten years. Rossi, meanwhile, has criticized Gregoire's $30 \%$ increase in state spending.

\section{MICHIGAN}

Embryo donation and medical marijuana

Voters will consider amending the state constitution to ease restrictions on embryonic stem cell research. Over 570,000 Michigan voters signed a petition to include this proposed amendment on the ballot, which would allow people receiving fertility treatments to donate embryos that would otherwise be discarded to research. The ballot also gives voters a chance to approve a state statute that would legalize marijuana for medicinal use.

\section{Congressional race}

Pointing to his $100 \%$ pro-life voting record in his 16 years in the Michigan House of Representatives, incumbent Tim Walberg pledges to continue ardently defending the sanctity of human life. Claiming embryonic stem cell research has yielded "consistently disappointing and fruitless results," Walberg calls upon Congress to catch up with recent advances in stem cell research using adult cells and amniotic fluid. Walberg is in a neck-and-neck race with Mark Schauer, a Democratic state senator who favors expanding federally funded research using embryonic stem cells.
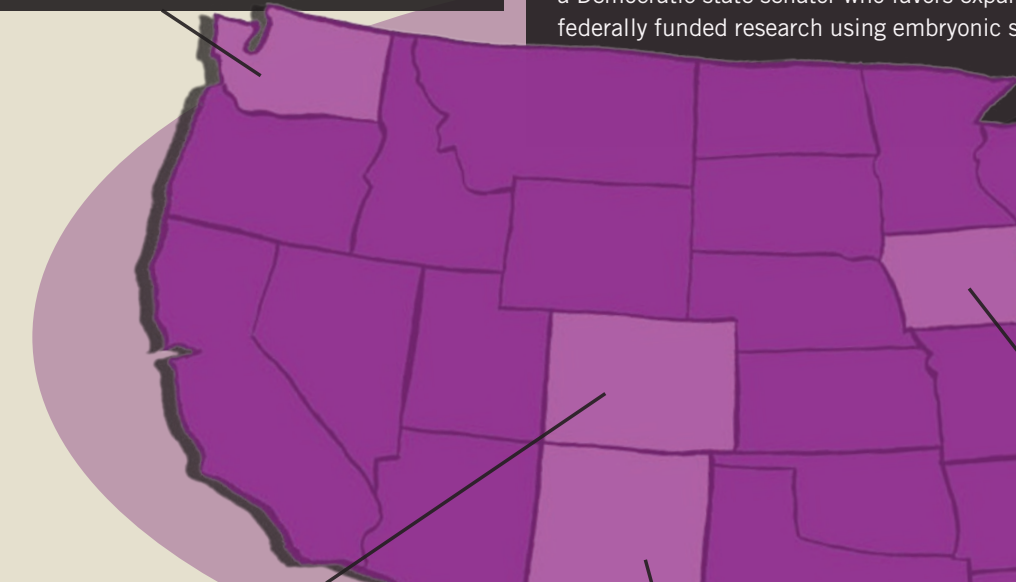

\section{COLORADO}

\section{Embryo rights}

Voters will decide whether to amend the state constitution to define personhood as beginning at the moment of fertilization. If passed, the citizen-initiated amendment is likely to spark new controversy over stem cell research, birth control and abortion rights.

\section{Senate race}

Experts anticipate a close Senate race between Democratic Congressman Mark Udall and the state's former Republican Congressman Bob Schaffer. Udall supports embryonic stem cell research and has voted against bans on human cloning for reproduction and medical research purposes. He also wants to see an $8-10 \%$ increase in funding for the US National Institutes of Health (NIH). Schaffer has voted against human cloning and opposes federal funding of stem cell research involving the intentional destruction of live human embryos.

\section{NEW HAMPSHIRE}

\section{Senate race}

Incumbent Republican John Sununu may be in for a tough fight in New Hampshire, where Democrats have recently been gaining ground. Supporters of embryonic stem cell research have suggested that Sununu blocked the passage of the Stem Cell Research Enhancement Act of 2007 because he failed to provide the one Senate vote necessary to override President Bush's veto. Sununu's Democratic rival, former governor Jeanne Shaheen, says she will work to overturn the restriction on federal funding for research on embryonic stem cell research lines created after August 2001 